\title{
Ischaemic stroke, haemorrhage, and mortality in older patients with chronic kidney disease newly started on anticoagulation for atrial fibrillation: a population based study from UK primary care
}

\author{
Shankar Kumar, ${ }^{1}$ Simon de Lusignan, ${ }^{2}$ Andrew McGovern, ${ }^{2,3}$ Ana Correa, ${ }^{2,4}$ Mariya Hriskova, ${ }^{2,4}$ \\ Piers Gatenby, ${ }^{2,5}$ Simon Jones, ${ }^{2,6}$ David Goldsmith,, ${ }^{7,8}$ A John Camm ${ }^{7}$
}

${ }^{1}$ Centre for Medical Imaging, University College London, London, UK

${ }^{2}$ Department of Clinical and Experimental Medicine, University of Surrey, Guildford, UK

${ }^{3}$ Exeter Medical School, University of Exeter, Exeter, UK

${ }^{4}$ Royal College of General Practitioners Research and Surveillance Centre, London, UK ${ }^{5}$ Royal Surrey County Hospital NHS Foundation Trust, Guildford, UK

${ }^{6}$ Department of Population Health, Division of Healthcare Delivery Science, NYU School of Medicine, New York, USA

${ }^{7}$ Molecular and Clinical Sciences Research Institute, St George's

University of London, UK

${ }^{8}$ Renal and Transplantation Department, Guys and St Thomas' Hospitals NHS

Foundation Trust, London, UK

Correspondence to: J Camm jcamm@sgul.ac.uk

Cite this as: $B M J$ 2018;360:k342 http://dx.doi.org/10.1136/bmj.k342

Accepted: 9 January 2018

\section{ABSTRACT}

OBJECTIVE

To assess the association between anticoagulation, ischaemic stroke, gastrointestinal and cerebral haemorrhage, and all cause mortality in older people with atrial fibrillation and chronic kidney disease.

\section{DESIGN}

Propensity matched, population based, retrospective cohort analysis from January 2006 through December 2016.

\section{SETTING}

The Royal College of General Practitioners Research and Surveillance Centre database population of almost 2.73 million patients from 110 general practices across England and Wales.

\section{PARTICIPANTS}

Patients aged 65 years and over with a new diagnosis of atrial fibrillation and estimated glomerular filtration rate (eGFR) of $<50 \mathrm{~mL} / \mathrm{min} / 1.73 \mathrm{~m}^{2}$, calculated using the chronic kidney disease epidemiology collaboration creatinine equation. Patients with a previous diagnosis of atrial fibrillation or receiving anticoagulation in the preceding 120 days were excluded, as were patients requiring dialysis and recipients of renal transplants.

\section{INTERVENTION}

Receipt of an anticoagulant prescription within 60 days of atrial fibrillation diagnosis.

MAIN OUTCOME MEASURES

Ischaemic stroke, cerebral or gastrointestinal haemorrhage, and all cause mortality.

\section{WHAT IS ALREADY KNOWN ON THIS TOPIC}

Optimal management of older patients with chronic kidney disease not requiring dialysis and concomitant atrial fibrillation is hindered by a lack of high quality clinical guidelines or randomised controlled trial evidence to support clinical decision making

Risk of stroke and haemorrhage in this patient group increases progressively with declining renal function, which makes the decision over whether to start anticoagulants difficult

The few observational studies that exist in the literature have conflicting findings

\section{WHAT THIS STUDY ADDS}

Anticoagulation was associated with an increased rate of ischaemic stroke and haemorrhage but lower all cause mortality

These paradoxical findings emphasise the urgent need for adequately powered randomised controlled trials to provide clarity on correct clinical management

Given the present lack of guidelines, the decision to start anticoagulant treatment in patients with chronic kidney disease and new onset atrial fibrillation should be made on an individual basis

\section{RESULTS}

6977 patients with chronic kidney disease and newly diagnosed atrial fibrillation were identified, of whom 2434 were on anticoagulants within 60 days of diagnosis and 4543 were not. 2434 pairs were matched using propensity scores by exposure to anticoagulant or none and followed for a median of 506 days. The crude rates for ischaemic stroke and haemorrhage were 4.6 and 1.2 after taking anticoagulants and 1.5 and 0.4 in patients who were not taking anticoagulant per 100 person years, respectively. The hazard ratios for ischaemic stroke, haemorrhage, and all cause mortality for those on anticoagulants were 2.60 (95\% confidence interval 2.00 to 3.38), 2.42 (1.44 to 4.05), and 0.82 (0.74 to 0.91 ) compared with those who received no anticoagulation.

\section{CONCLUSION}

Giving anticoagulants to older people with concomitant atrial fibrillation and chronic kidney disease was associated with an increased rate of ischaemic stroke and haemorrhage but a paradoxical lowered rate of all cause mortality. Careful consideration should be given before starting anticoagulants in older people with chronic kidney disease who develop atrial fibrillation. There remains an urgent need for adequately powered randomised trials in this population to explore these findings and to provide clarity on correct clinical management.

\section{Introduction}

Atrial fibrillation is the most frequently occurring sustained cardiac arrhythmia worldwide. ${ }^{12}$ It affects at least 33.5 million people aged over 55 years globally and is predicted to more than double over the next 50 years. It is associated with increased morbidity from thromboembolic stroke and from cardiac failure, and all cause mortality. ${ }^{3-7}$ The economic burden of atrial fibrillation accounts for $1 \%$ of the NHS budget in the UK and up to $\$ 26 \mathrm{bn}$ ( $€ 19 \mathrm{bn}$; €21bn) a year in the USA. ${ }^{8-10}$

Chronic kidney disease affects around 10-15\% of adults globally. Around one third of cases have concomitant atrial fibrillation; shared risk factors include hypertension, dyslipidaemia, coronary artery disease, and diabetes mellitus. ${ }^{11-13}$ In this patient population, the risk of stroke and haemorrhage increases progressively as the estimated glomerular filtration rate (eGFR) declines, which complicates the decision over whether to initiate anticoagulation. Research has focused more on end stage renal disease even though it accounts for less than $1 \%$ of atrial 
fibrillation cases. ${ }^{14}$ No randomised controlled trial has been performed in the patients with chronic kidney disease who are not on dialysis. The few observational studies of anticoagulation in patients with chronic kidney disease who are not on dialysis have yielded conflicting results and are hampered by modest sample size, ${ }^{14-19}$ highly selected populations, ${ }^{20}$ and suboptimal methods for identifying chronic kidney disease. ${ }^{182122}$

Chronic kidney disease is most prevalent in older people. In the US, almost $40 \%$ of those aged over 60 years have chronic kidney disease compared with $11 \%$ in the general population. ${ }^{23}$ In those aged 65 and over, atrial fibrillation affects over $20 \%$ of patients with non-dialysis chronic kidney disease and $27 \%$ of those with end stage renal disease, compared with only $6 \%$ in the general population. ${ }^{24} 25$ Taken together, older patients with chronic kidney disease and atrial fibrillation are an increasing healthcare burden yet are poorly studied.

In the absence of chronic kidney disease, anticoagulation confers protection against ischaemic stroke compared with no antithrombotic agent or antiplatelet agents alone. ${ }^{26}$ But the net clinical benefits in chronic kidney disease are less certain given the greater risk of haemorrhage and other effects on overall survival. ${ }^{27}$ Over a quarter of older patients discontinue warfarin in the first year of prescription because of perceived safety concerns. ${ }^{28}$ Older people are less likely to be offered anticoagulant drugs than are their younger counterparts, based on comorbidities and other personal characteristics, such as risk of falls, rather than on the results of established clinical scoring systems. ${ }^{29}$

Only two studies, both from Canada, have reported the outcomes of anticoagulating older people with atrial fibrillation and intercurrent non-end stage chronic kidney disease, with conflicting findings. ${ }^{30}{ }^{31}$ The first, a population based study from Ontario, showed that anticoagulation did not prevent ischaemic stroke but was associated with a higher rate of haemorrhage and with improved survival. By contrast, data from the Alberta Kidney Disease Network showed that warfarin was associated with a significantly lower risk of a composite outcome (all cause death, ischaemic stroke, and transient ischaemic attack) at one year, with excess bleeding only seen in those with an eGFR of $60-89 \mathrm{ml} / \mathrm{min} / 1.73 \mathrm{~m}^{2}$. Given the paucity of trial data, the conflicting outcome data from the small number of studies, and the lack of specific clinical practice guidelines in this important and frequently occurring clinical setting, we explored the association between ischaemic stroke, haemorrhage, and mortality in a large population of older patients with chronic kidney disease and newly diagnosed atrial fibrillation, some of whom were on anticoagulants.

\section{Methods}

Data source, study design, and ethics

We conducted this population based, retrospective, cohort study using the Royal College of General
Practitioners (RCGP) Research and Surveillance Centre database, one of the oldest primary care sentinel networks, comprising nearly 2.73 million patients across 110 general practices in the UK. ${ }^{32}$ The network monitors data from $1.7 \%$ of all general practices in England, with ongoing patient recruitment, and is representative of the general UK population. ${ }^{32} 33$

The study was tested against the Health Research Authority and Medical Research Council guidance for identifying research and was deemed to be an audit of current practice so specific ethical approval was not required. The protocol was approved by the RCGP. We adhered to the STROBE statement for reporting observational studies. ${ }^{34}$

\section{Study population}

The study spanned an 11 year period from 1 January 2006 to 31 December 2016. We included patients aged 65 years or older with a new diagnosis of atrial fibrillation and eGFR $<50 \mathrm{ml} / \mathrm{min} / 1.73 \mathrm{~m}^{2}$, calculated using the chronic kidney disease epidemiology collaboration creatinine equation with more than one eGFR value (fig 1). ${ }^{35}$ We chose this level of renal impairment to align our study with previous major phase III anticoagulation trials. ${ }^{36-39}$ We excluded patients with a previous diagnosis of atrial fibrillation, those in receipt of a prescription for anticoagulation in the 120 days before diagnosis, those on chronic dialysis, and recipients of renal transplants. Atrial fibrillation was defined by Read codes ${ }^{40}$ from the primary care database using diagnostic and process of care codes to maximise case identification..$^{41}$ In the UK, patients can be registered with only a single primary care provider or general practice, and records of all secondary care events are sent to the patient's general practitioner. Diagnoses are coded into the primary care record, so UK primary care records provide a robust list of a patient's diagnoses made in both primary and secondary care.

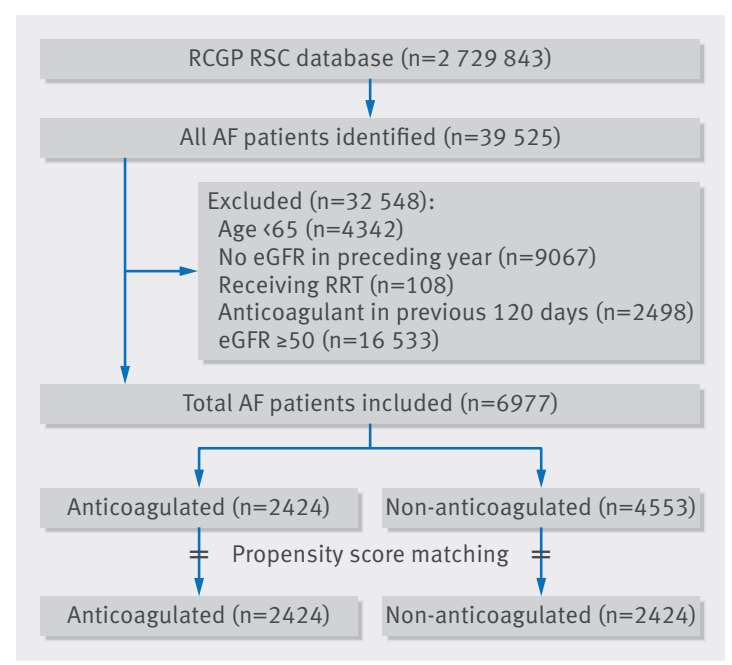

Figure 1 | Study population. $A F=$ atrial fibrillation; eGFR=estimated glomerular filtration rate; RRT=renal replacement therapy; RCGP RSC=Royal College of General Practitioners Research and Surveillance Centre 


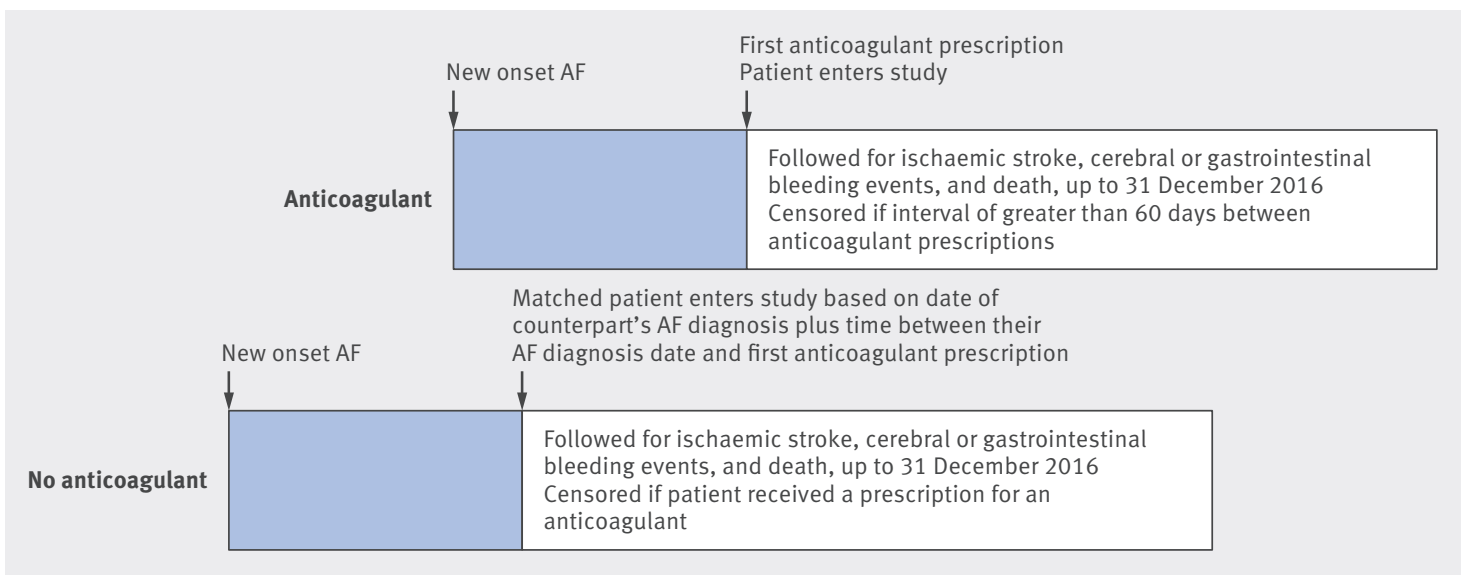

Fig 2 | Study design. Timeline showing how patients taking anticoagulants and their matched counterparts not on anticoagulants were followed in the study

\section{Study design}

Patients on anticoagulants entered the study (the time at which outcome ascertainment began) on the day they received their first anticoagulant prescription within 60 days of their diagnosis of atrial fibrillation. Patients who received anticoagulation were propensity matched in a 1:1 ratio with those who were not anticoagulated and were alive at the time of the first dispensed prescription to their matched counterpart. To mitigate the effect of immortal time bias, the date that the patient who was not on an anticoagulant entered the study coincided with the date that they received a diagnosis of atrial fibrillation plus the time between their matched counterpart's diagnosis of atrial fibrillation and first anticoagulant prescription (fig 2). ${ }^{3142}$

\section{Patient involvement}

No patients were involved in setting the research question or the outcome measures, nor were they involved in developing plans for recruitment, design, or implementation of the study. No patients were asked to advise on interpretation or reporting the results. There are no plans to disseminate the results of the research to study participants or the relevant patient community.

\section{Exposure and outcome measures}

Exposure was defined as receipt of a prescription for anticoagulants within 60 days of receiving a diagnosis of atrial fibrillation. Almost all anticoagulant prescriptions in the UK are issued from primary care and are, therefore, captured in the RCGP Research and Surveillance Centre database, except when the anticoagulant is started in hospital. The 60 day period allowed for the transfer of anticoagulant prescribing to primary care from secondary care.

Anticoagulants included vitamin $\mathrm{K}$ antagonists, direct oral anticoagulants, and heparin based compounds (full dose for anticoagulation). Outcomes were ischaemic stroke including transient ischaemic attack, gastrointestinal or cerebral haemorrhage, and all cause mortality, using previously published Read codes. ${ }^{43} 44$ Unclassified strokes were combined with ischaemic strokes, an approach used in other studies, ${ }^{45}$ because about $87 \%$ of all strokes have ischaemic aetiology ${ }^{46}$ Study participants were followed for ischaemic stroke, cerebral or gastrointestinal bleeding events, and death up to 31 December 2016. We censored patients who had an interval of greater than 60 days between anticoagulant prescriptions, a timeframe that reflects the typical duration of an anticoagulant prescription issued in UK primary care. Patients who were not on anticoagulants were censored at the time of receipt of first anticoagulant prescription. ${ }^{30}$

\section{Statistical analysis}

Data analysis was performed using R (http://www.rproject.org), version 2.15.0, and statistical significance was defined as a $\mathrm{P}$ value less than 0.05 with two sided testing. We used propensity score matching with demographic and clinical variables to adjust for potential confounding from imbalances in clinical characteristics between patients receiving and not receiving anticoagulation. Demographic variables were age, sex, year of atrial fibrillation diagnosis, and index of multiple deprivation (IMD) decile. The IMD is derived from patient postcode and is the official national measure of deprivation. It provides a combined measure of household income, education, healthcare provision, and living environment for the UK at small spatial scales. ${ }^{47}$ Clinical variables were smoking status, eGFR, comorbidities at baseline (myocardial infarction, coronary artery disease, cardiac failure, type 2 diabetes mellitus, hypertension, history of previous stroke or transient ischaemic attack, previous cerebral or gastrointestinal bleed, peripheral artery disease), and drugs at baseline (antiplatelet agents excluding aspirin, angiotensin converting enzyme inhibitors, angiotensin II receptor blockers, lipid lowering drugs, $\square$ blockers, aspirin, potassium sparing diuretics, supraventricular and ventricular antiarrhythmic agents, thiazide diuretics, calcium channel blockers, $\square$ blockers, loop diuretics, insulin, metformin, cardiac glycosides). 
Patients who received anticoagulation were matched in a 1:1 ratio with those who were not anticoagulated, and differences in clinical characteristics were assessed using standardised differences, with values $<0.1$ considered well balanced. We calculated the incidence of ischaemic stroke, haemorrhage, and all cause mortality per 100 person years of followup. We generated Kaplan-Meier survival curves for the outcomes of interest grouped by anticoagulation status. Cox proportion regression were reported as adjusted hazard ratios with $95 \%$ confidence intervals. Because all baseline characteristics were balanced in the propensity matched model, receipt of anticoagulation was the only independent variable in our Cox regression model.

\section{Sensitivity analyses}

We undertook a series of sensitivity analyses to confirm our findings. We performed an intention to treat analysis, in which we did not censor patients after starting anticoagulants, irrespective of the time interval between anticoagulant prescriptions. We repeated the analysis censoring patients at an interval of 160 days between anticoagulation prescriptions (rather than 60 days used in the primary analysis) to detect additional events after discontinuation of anticoagulation.

\section{Results}

\section{Baseline characteristics of all patients}

A total of 6977 patients met the inclusion criteria of being aged 65 years or older with a new diagnosis of atrial fibrillation and eGFR $<50 \mathrm{ml} / \mathrm{min} / 1.73 \mathrm{~m}^{2}$ (fig 1). Of these, 2424 received an anticoagulant within 60 days of diagnosis. The anticoagulants used were vitamin $\mathrm{K}$ antagonists (1739, 71.7\%), rivaroxaban $(307,12.7 \%)$, apixaban $(261,10.8 \%)$, dabigatran $(69$, $2.8 \%$ ) unfractionated or low molecular weight heparin (44, 1.8\%), and edoxaban (4, 0.17\%). The mean number of days from atrial fibrillation diagnosis to first prescription of an anticoagulant was 17.8 (range 0-59, interquartile range 2-29).

Before matching, patients prescribed anticoagulants tended to be younger (mean 81.7 years $v 83.2$ years), female $(54.7 \%)$, and not current smokers $(8.6 \% \mathrm{~V}$ $12.1 \%)$, compared with those not on anticoagulants (table 1). The groups were well matched in the index of deprivation decile. Patients on anticoagulants were less likely to have previous cerebral $(0.7 \% \mathrm{~V} 1.6 \%)$ or gastrointestinal haemorrhage $(2.8 \%$ v $5.1 \%)$. The mean $\mathrm{CHA}_{2} \mathrm{DS}_{2}$-VASc (Congestive heart failure, Hypertension, Age $\geq 75$ years, Diabetes mellitus, previous Stroke/ transient ischaemic attack, Vascular disease, Age 6574 years, Sex category; age $\geq 75$ years and previous stroke carry doubled risk weight) score of 4.2 (standard deviation \pm 1.2 ) did not differ between the groups, and the mean eGFR was also similar in patients who did and did not receive anticoagulants (38.6 v 37.4). Coronary artery disease was more frequent in the anticoagulant group (14.0\% $v 10.2 \%)$, as was the prescription of angiotensin converting enzyme inhibitors $(46.8 \% \mathrm{~V}$ $34.9 \%)$, angiotensin II receptor blockers $(11.4 \% \mathrm{~V}$
7.4\%), $\square$ blockers (11.4\% v 7.4\%), $\square$ blockers $(62.8 \%$ $v 47.2 \%)$, thiazide diuretics (23.9\% v13.1\%), calcium channel blockers (39.4\% $v$ 26.7\%), lipid lowering agents (58.7\% $v$ 46.6\%), metformin (11.1\% $v 7.2 \%)$, and aspirin (16.3\% v 11.6\%).

\section{Propensity matched model}

In the propensity score matched cohort of 2424 pairs, we found no major differences between the two groups (table 1). The median follow-up duration was 506 days (interquartile range 175-1131) for the 4848 patients included in the analysis. There were a total of 309 ischaemic strokes (6.4\%), 79 gastrointestinal or cerebral haemorrhage events (1.6\%), and 1410 all cause fatalities (29.1\%). The crude rates for ischaemic stroke and haemorrhage were 4.6 and 1.2 after anticoagulation, and 1.5 and 0.4 in patients who did not take anticoagulants per 100 person years, respectively. Kaplan-Meier curves by receipt of anticoagulation for ischaemic stroke, haemorrhage, and all cause mortality are shown in figure 3. In the Cox proportion regression models, the hazard ratios for ischaemic stroke, haemorrhage and all cause mortality for patients on anticoagulants were 2.60 (95\% confidence interval 2.00 to 3.38 ), 2.42 (1.44 to 4.05), and 0.82 (0.74 to 0.91) compared with those who received no anticoagulation.

These findings were consistent in the sensitivity analyses. In the intention to treat analysis, anticoagulation was associated with a higher hazard ratio for stroke $(2.62,2.04$ to 3.46$)$ and haemorrhage $(2.46,1.47$ to 4.09$)$, but was lower for all cause mortality $(0.84,0.75$ to 0.93$)$. Increased risk of stroke $(2.59,1.99$ to 3.37$)$ and haemorrhage $(2.41,1.44$ to $34.04)$ and reduced risk of all cause mortality (0.83, 0.76 to 0.92 ) persisted when using a 160 day interval between prescriptions as a censoring event. We found no fault in the proportional hazards assumption using the method of Grambsch and Therneau. ${ }^{48}$

\section{Discussion}

In this propensity matched, population based study of older people with chronic kidney disease and new onset atrial fibrillation, we found that anticoagulation was associated with an increased rate of ischaemic stroke and haemorrhage but a lower rate of all cause mortality. The crude rates of ischaemic stroke and haemorrhage were 4.6 and 1.2 after anticoagulation and 1.5 and 0.4 in patients with no anticoagulation per 100 person years, respectively. The hazard ratios for developing ischaemic stroke, haemorrhage, and all cause mortality in the anticoagulant group were 2.60 (2.00 to 3.38), 2.42 (1.44 to 4.05), and 0.82 (0.74 to 0.91 ) compared with their counterparts who did not receive anticoagulants. These findings were consistent after performing several sensitivity analyses.

For the general population, overwhelming evidence from large scale randomised controlled trials supports oral anticoagulation in the context of atrial fibrillation for stroke thromboprophylaxis, and this has been 
Table 1 | Demographic and clinical characteristics of the study cohort before and after propensity score matching. Figures are $\mathrm{n}(\%)$ unless otherwise stated.

\begin{tabular}{|c|c|c|c|c|c|c|}
\hline & \multicolumn{3}{|l|}{ Before matching } & \multicolumn{3}{|l|}{ After matching } \\
\hline & Anticoagulants & $\begin{array}{l}\text { No } \\
\text { anticoagulants }\end{array}$ & $\begin{array}{l}\text { Standardised } \\
\text { mean difference }\end{array}$ & Anticoagulants & $\begin{array}{l}\text { No } \\
\text { anticoagulants }\end{array}$ & $\begin{array}{l}\text { Standardised } \\
\text { mean difference }\end{array}$ \\
\hline Total & 2424 & 4553 & - & 2424 & 2424 & - \\
\hline Mean age (SD) & $81.7(7.2)$ & $83.2(7.1)$ & 0.24 & $81.7(7.2)$ & $81.9(7.4)$ & 0.03 \\
\hline Men & $1098(45.3)$ & $2747(60.3)$ & 0.11 & $1098(45.3)$ & $1072(44.2)$ & 0.01 \\
\hline Women & $1326(54.7)$ & $186(40.9)$ & 0.11 & $1326(54.7)$ & $1352(55.8)$ & 0.01 \\
\hline \multicolumn{7}{|l|}{ IMD decile: } \\
\hline 1 & $134(5.5)$ & $264(5.8)$ & 0.02 & $134(5.5)$ & $142(5.9)$ & 0.02 \\
\hline 2 & $162(6.7)$ & $330(7.2)$ & 0.02 & $162(6.7)$ & $176(7.3)$ & 0.02 \\
\hline 3 & $186(7.7)$ & $324(7.1)$ & 0.02 & $186(7.7)$ & $177(7.3)$ & 0.01 \\
\hline 4 & $180(7.4)$ & $421(9.2)$ & 0.07 & $180(7.4)$ & $201(8.3)$ & 0.03 \\
\hline 5 & $234(9.7)$ & $459(10.1)$ & 0.01 & $234(9.7)$ & $243(10.0)$ & 0.00 \\
\hline 6 & $214(8.8)$ & $477(10.5)$ & 0.06 & $214(8.8)$ & $221(9.1)$ & 0.00 \\
\hline 7 & $282(11.6)$ & $556(12.2)$ & 0.02 & $282(11.6)$ & 288 (11.9) & 0.00 \\
\hline 8 & $330(13.6)$ & 604 (13.3) & 0.01 & $330(13.6)$ & $327(13.5)$ & 0.00 \\
\hline 9 & $355(14.6)$ & $602(13.2)$ & 0.04 & $355(14.6)$ & 337 (13.9) & 0.00 \\
\hline 10 & $343(14.2)$ & $502(11)$ & 0.09 & $343(14.2)$ & $308(12.7)$ & 0.04 \\
\hline Missing & $4(0.2)$ & $14(0.3)$ & 0.04 & $4(0.2)$ & $4(0.2)$ & 0.00 \\
\hline \multicolumn{7}{|l|}{ Smoking: } \\
\hline Active & 209 (8.6) & $551(12.1)$ & 0.15 & 209 (8.6) & $226(9.3)$ & 0.04 \\
\hline Former & $1557(64.2)$ & $2700(59.3)$ & 0.10 & $1557(64.2)$ & $1555(64.2)$ & 0.02 \\
\hline Non-smoker & $630(26.0)$ & 1179 (25.9) & 0.00 & $630(26.0)$ & $619(25.5)$ & 0.01 \\
\hline Missing & $28(1.2)$ & $123(2.7)$ & 0.14 & $28(1.2)$ & $24(1.0)$ & 0.01 \\
\hline Type 2 diabetes & $629(25.9)$ & $1075(23.6)$ & 0.05 & $629(25.9)$ & $598(24.7)$ & 0.02 \\
\hline Coronary artery disease & $340(14.0)$ & $465(10.2)$ & 0.11 & $340(14.0)$ & $325(13.4)$ & 0.01 \\
\hline $\begin{array}{l}\text { History of myocardial } \\
\text { infarction }\end{array}$ & $410(16.9)$ & $823(18.1)$ & 0.03 & $410(16.9)$ & $432(17.8)$ & 0.03 \\
\hline Hypertension & $1950(80.4)$ & $3522(77.4)$ & 0.08 & $1950(80.4)$ & $1938(80.0)$ & 0.00 \\
\hline $\begin{array}{l}\text { Peripheral artery } \\
\text { disease }\end{array}$ & $224(9.2)$ & $463(10.2)$ & 0.03 & $224(9.2)$ & $243(10.0)$ & 0.03 \\
\hline Heart failure & $533(22.0)$ & $1107(24.3)$ & 0.06 & $533(22.0)$ & $552(22.8)$ & 0.02 \\
\hline $\begin{array}{l}\text { Previous ischaemic } \\
\text { stroke or TIA }\end{array}$ & $525(21.7)$ & $1034(22.7)$ & 0.03 & $525(21.7)$ & $532(21.9)$ & 0.02 \\
\hline $\begin{array}{l}\text { Previous GI haemor- } \\
\text { rhage }\end{array}$ & $67(2.8)$ & $232(5.1)$ & 0.14 & $67(2.8)$ & $61(2.5)$ & 0.00 \\
\hline $\begin{array}{l}\text { Previous cerebral haem- } \\
\text { orrhage }\end{array}$ & $18(0.7)$ & $73(1.6)$ & 0.11 & $18(0.7)$ & $15(0.6)$ & 0.00 \\
\hline eGFR (SD)* & $38.6(9.2)$ & $37.4(9.0)$ & 0.04 & $38.6(9.2)$ & $38.4(9.4)$ & 0.04 \\
\hline \multicolumn{7}{|l|}{ Medications: } \\
\hline ACE-I & $1134(46.8)$ & $1588(34.9)$ & 0.24 & $1134(46.8)$ & $1060(43.7)$ & 0.05 \\
\hline ARB & $276(11.4)$ & $338(7.4)$ & 0.12 & $276(11.4)$ & $246(10.1)$ & 0.04 \\
\hline a blocker & $276(11.4)$ & $338(7.4)$ & 0.12 & $276(11.4)$ & $246(10.1)$ & 0.04 \\
\hline$\beta$ locker & $1522(62.8)$ & $2150(47.2)$ & 0.32 & $1522(62.8)$ & $1453(59.9)$ & 0.06 \\
\hline Thiazide diuretic & $580(23.9)$ & $595(13.1)$ & 0.25 & $580(23.9)$ & $476(19.6)$ & 0.09 \\
\hline Loop diuretic & $1035(42.7)$ & $1809(39.7)$ & 0.06 & $1035(42.7)$ & $1011(41.7)$ & 0.00 \\
\hline $\mathrm{CCB}$ & $955(39.4)$ & $1217(26.7)$ & 0.26 & $955(39.4)$ & $867(35.8)$ & 0.08 \\
\hline $\begin{array}{l}\text { Potassium sparing } \\
\text { diuretics }\end{array}$ & $210(8.7)$ & $284(6.2)$ & 0.09 & $210(8.7)$ & $197(8.1)$ & 0.02 \\
\hline Lipid Lowering agent & $1423(58.7)$ & $2121(46.6)$ & 0.25 & $1423(58.7)$ & $1360(56.1)$ & 0.03 \\
\hline $\begin{array}{l}\text { Anti-platelet agents } \\
\text { excluding aspirin }\end{array}$ & $1427(58.9)$ & $2885(63.4)$ & 0.09 & $1427(58.9)$ & $1488(61.4)$ & 0.06 \\
\hline $\begin{array}{l}\text { Supraventricular anti- } \\
\text { arrhythmics }\end{array}$ & $102(4.2)$ & $249(5.5)$ & 0.06 & $102(4.2)$ & $96(4.0)$ & 0.02 \\
\hline Cardiac glycosides & $376(15.5)$ & $845(18.6)$ & 0.08 & $376(15.5)$ & $380(15.7)$ & 0.02 \\
\hline $\begin{array}{l}\text { Ventricular } \\
\text { antiarrhythmics }\end{array}$ & $98(4.0)$ & $226(5.0)$ & 0.05 & $98(4.0)$ & $92(3.8)$ & 0.02 \\
\hline Metformin & $269(11.1)$ & $327(7.2)$ & 0.12 & $269(11.1)$ & $226(9.3)$ & 0.05 \\
\hline Insulin & $156(6.4)$ & $215(4.7)$ & 0.07 & $156(6.4)$ & $146(6.0)$ & 0.01 \\
\hline Aspirin & $396(16.3)$ & $527(11.6)$ & 0.13 & $396(16.3)$ & $336(13.9)$ & 0.05 \\
\hline
\end{tabular}

${ }^{*}$ measured in $\mathrm{mL} / \mathrm{min} / 1.73 \mathrm{~m}^{2}$

$\mathrm{ACE}-\mathrm{I}=$ angiotensin converting enzyme inhibitor; $\mathrm{ARB}=$ angiotensin $\mid$ receptor blocker; $C C B=$ calcium channel blocker; eGFR, estimated glomerular filtration rate; $\mathrm{Gl}=$ gastrointestinal; IMD=index of multiple deprivation; $\mathrm{SD}=$ standard deviation; $\mathrm{TIA}=$ transient ischaemic attack. 

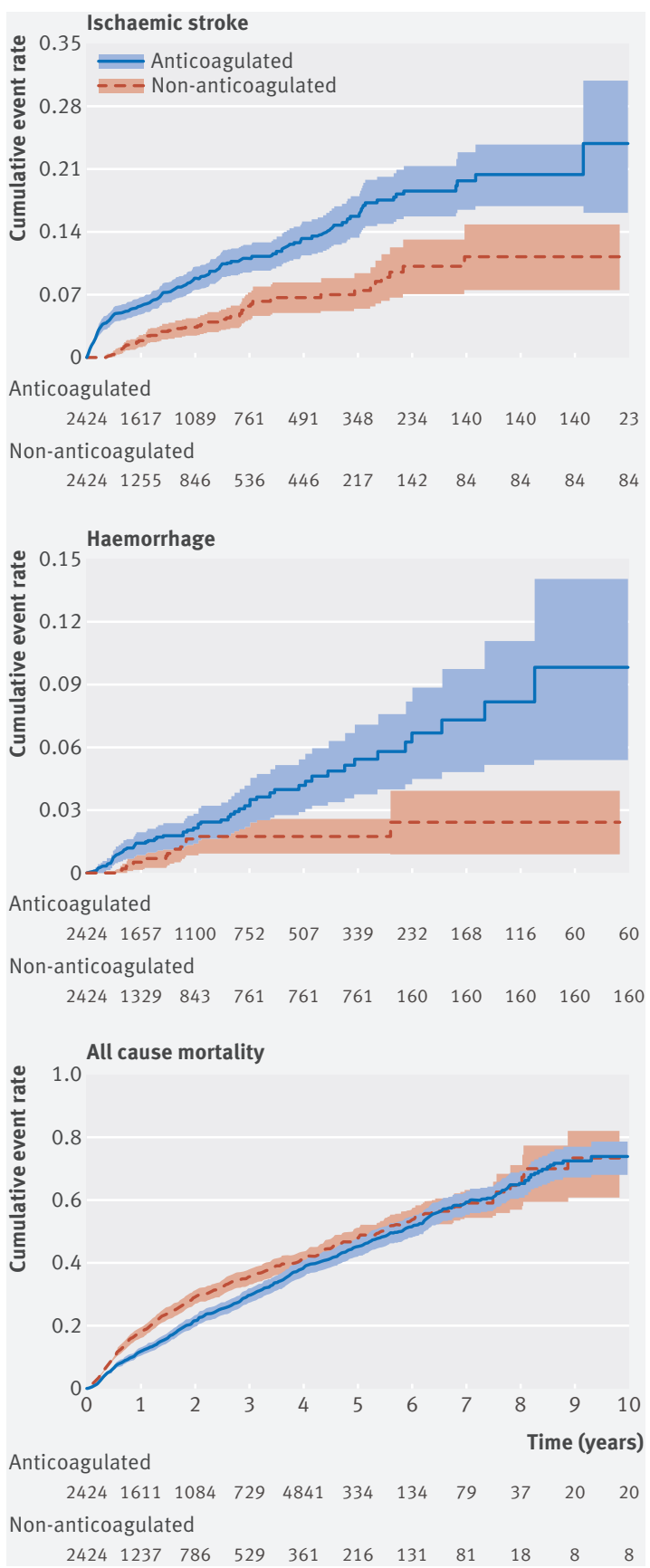

Fig 3 | Kaplan-Meier survival curve by anticoagulation status

universally adopted in clinical practice guidelines. ${ }^{49}$ ${ }^{50}$ However, this may not apply in patients with atrial fibrillation and concurrent chronic kidney disease. Anticoagulation for atrial fibrillation in patients requiring chronic dialysis is a contentious issue, lacking convincing data from randomised controlled trials. ${ }^{51}$ Large studies have shown a doubling in risk of stroke after anticoagulation ${ }^{5253}$ and a heightened risk of intracranial haemorrhage and major systemic bleeding. ${ }^{54} 55$ Subsequent meta-analyses, however, have found no association between anticoagulation and ischaemic stroke, but a continued risk of major bleeding events remains. ${ }^{5657}$
The role of anticoagulation in patients with chronic kidney disease not on dialysis is even less certain. In our cohort, $35 \%$ of patients were in receipt of an anticoagulant prescription, though rates of 23\%-45\% have been reported in the published literature. ${ }^{21} 30$ ${ }^{31}$ Data on the efficacy and safety of anticoagulants in people with chronic kidney disease not requiring dialysis and concurrent atrial fibrillation are lacking (table 2). A study in this population from Danish national registries found that warfarin was not associated with a statistically significant decrease in risk of stroke and systemic thromboembolism, but both warfarin and aspirin increased bleeding risk. ${ }^{21}$ A limitation of the study, however, was the absence of data pertaining to the degree of renal impairment, with broad categorisation of patients into those with no renal impairment, those with chronic kidney disease not needing dialysis, or those requiring renal replacement therapy. Carrero and colleagues followed survivors of acute myocardial infarction with atrial fibrillation who were prescribed warfarin before being discharged from hospital. ${ }^{20}$ In this cohort, patients with all stages of chronic kidney disease, including those needing dialysis, who took anticoagulants had lower rates of ischaemic stroke and all cause mortality and no significant increased risk of major bleeding. This highly selected population, however, limits the generalisability of their observations.

Our study corroborates the results of a large prospective study that found that patients with chronic kidney disease and atrial fibrillation who received anticoagulants had reduced all cause mortality and increased bleeding. ${ }^{19}$ However, contrary to our findings, there was a reduction in the incidence of ischaemic strokes. A 15 year, register based, cohort study from Denmark found that warfarin was associated with a higher rate of bleeding in patients with chronic kidney disease, with the exception of those with stage I disease, and with a lower rate of stroke in non-end stage chronic kidney disease. ${ }^{22}$ Results from a Canadian healthcare database indicated that giving anticoagulants to older patients with chronic kidney disease not requiring dialysis and with an eGFR of $\leq 45 \mathrm{~mL} / \mathrm{min} / 1.73 \mathrm{~m}^{2}$ did not reduce risk of ischaemic stroke and induced major haemorrhage but was associated with significantly less mortality. A time varying analysis of their cohort raised the possibility that anticoagulation might increase the risk of ischaemic stroke. Most recently, in a cohort of older patients, Jun and colleagues found that warfarin use was associated with a significantly lower risk of the one year composite outcome of all cause death, ischaemic stroke, and transient ischaemic attack across all eGFR strata. Unexpectedly, warfarin was associated with 5-29\% fewer bleeding episodes, and excess haemorrhage noted only in patients with an eGFR of $60-89 \mathrm{~mL} / \mathrm{min} / 1.73 \mathrm{~m}^{2}$. This may reflect residual confounding in the study or incomplete outcome data.

We describe for the first time a paradoxical increase in ischaemic stroke associated with the receipt of an anticoagulant prescription in patients with chronic 


\begin{tabular}{|c|c|c|c|c|c|c|c|c|}
\hline Report & Study design & $\begin{array}{l}\text { Population } \\
\text { selection }\end{array}$ & Sample size & $\begin{array}{l}\text { Outcome of antico- } \\
\text { agulation versus no } \\
\text { anticoagulation }\end{array}$ & $\begin{array}{l}\text { Median } \\
\text { follow up } \\
\text { (years) }\end{array}$ & $\begin{array}{l}\text { Event rate per } \\
100 \text { person years } \\
(95 \% \mathrm{Cl}) \text { in study } \\
\text { population }\end{array}$ & $\begin{array}{l}\text { Hazard ratio or } \\
\text { relative risk for } \\
\text { anticoagulation } \\
(95 \% \mathrm{Cl})\end{array}$ & Summary of findings \\
\hline $\begin{array}{l}\text { Olesen } \\
\text { JB et al, } \\
2012^{21}\end{array}$ & Retrospective & $\begin{array}{l}\text { All patients with } \\
\text { AF at hospital } \\
\text { discharge. ND- } \\
\text { CKD defined by } \\
\text { ICD codes }\end{array}$ & $\begin{array}{l}\mathrm{n}=3587 \\
609 \text { on antico- } \\
\text { agulants }\end{array}$ & $\begin{array}{l}\text { Stroke: no effect } \\
\text { Bleeding: increased }\end{array}$ & NA & $\begin{array}{l}\text { Stroke: } 6.44(6.02 \\
\text { to } 6.89) \\
\text { Bleeding: } 8.77 \\
\text { (8.26 to } 9.30)\end{array}$ & $\begin{array}{l}\text { Stroke: } 0.84(0.69 \\
\text { to } 1.01) \\
\text { Bleeding: } 1.36 \\
\text { (1.17 to } 1.59)\end{array}$ & $\begin{array}{l}\text { Giving anticoagulants } \\
\text { to ND-CKD patients } \\
\text { increased bleeding } \\
\text { without reducing } \\
\text { strokes }\end{array}$ \\
\hline $\begin{array}{l}\text { Keskar } \\
\text { V et al, } \\
2017^{30}\end{array}$ & Retrospective & $\begin{array}{l}\text { Patients aged } \\
\geq 66 \text { years } \\
\text { with eGFR }<45 \\
\text { developing AF. } \\
\text { ESRD patients } \\
\text { excluded }\end{array}$ & $\begin{array}{l}\mathrm{n}=6554 \\
1417 \text { on } \\
\text { anticoagulants, } \\
1417 \text { propen- } \\
\text { sity matched } \\
\text { not on antico- } \\
\text { agulants }\end{array}$ & $\begin{array}{l}\text { Stroke: no effect } \\
\text { Bleeding: increased } \\
\text { All cause mortality: } \\
\text { reduced }\end{array}$ & $0.73^{*}$ & $\begin{array}{l}\text { Stroke: } 4.13(3.33 \\
\text { to } 5.07)^{\star} \\
\text { Bleeding: } 6.13 \\
(5.15 \text { to } 7.24)^{\star} \\
\text { All cause mortal- } \\
\text { ity: } 12.3(10.9 \text { to } \\
13.8)^{\star}\end{array}$ & $\begin{array}{l}\text { Stroke: } 1.10(0.78 \\
\text { to } 1.56) \\
\text { Bleeding: } 1.42 \\
\text { (1.04 to } 1.93) \\
\text { All cause mortality: } \\
0.74(0.62 \text { to } 0.88)\end{array}$ & $\begin{array}{l}\text { In older patients, anti- } \\
\text { coagulation was asso- } \\
\text { ciated with increased } \\
\text { bleeding and reduced } \\
\text { mortality, and had no } \\
\text { effect on stroke }\end{array}$ \\
\hline $\begin{array}{l}\text { Jun } M \\
\text { et al, } \\
2017^{31}\end{array}$ & Retrospective & $\begin{array}{l}\text { Patients aged } \\
\geq 66 \text { years with } \\
\text { available eGFR } \\
\text { data. ESRD pa- } \\
\text { tients excluded. }\end{array}$ & $\begin{array}{l}\mathrm{n}=21530 \\
7446 \text { on } \\
\text { anticoagulants, } \\
7446 \text { propen- } \\
\text { sity matched } \\
\text { not on antico- } \\
\text { agulants }\end{array}$ & $\begin{array}{l}\text { Composite outcome } \\
\text { at } 1 \text { year for all cause } \\
\text { death, ischaemic } \\
\text { stroke, and TIA: } \\
\text { eGFR } 290 \text { : reduced } \\
\text { eGFR 60-89: reduced } \\
\text { eGFR 45-59: reduced } \\
\text { eGFR 30-44: reduced } \\
\text { eGFR <30: reduced }\end{array}$ & NA & NA & $\begin{array}{l}\text { eGFR } \geq 90: 0.59 \\
(0.35 \text { to } 1.01) \\
\text { eGFR 60-89: } 0.61 \\
\text { (0.54 to 0.70) } \\
\text { eGFR 45-59: } 0.55 \\
(0.47 \text { to } 0.65) \\
\text { eGFR } 30-44: 0.54 \\
(0.44 \text { to } 0.67) \\
\text { eGFR <30: } 0.64 \\
(0.47 \text { to } 0.87)\end{array}$ & $\begin{array}{l}\text { In older patients, } \\
\text { anticoagulation re- } \\
\text { duced the composite } \\
\text { outcome at } 1 \text { year } \\
\text { for death, ischaemic } \\
\text { stroke, and TIA }\end{array}$ \\
\hline $\begin{array}{l}\text { Current } \\
\text { study }\end{array}$ & Retrospective & $\begin{array}{l}\text { Patients aged } \\
\geq 65 \text { years with } \\
\text { an eGFR of }<50 \\
\text { developing AF. } \\
\text { ESRD patients } \\
\text { excluded. }\end{array}$ & $\begin{array}{l}\mathrm{n}=6977 \\
2434 \text { on } \\
\text { anticoagulants, } \\
2434 \text { propen- } \\
\text { sity matched } \\
\text { not on antico- } \\
\text { agulants }\end{array}$ & $\begin{array}{l}\text { Stroke: increased } \\
\text { Bleeding: increased } \\
\text { All cause mortality: } \\
\text { reduced }\end{array}$ & $\begin{array}{l}1.39 \\
\text { overall }\end{array}$ & $\begin{array}{l}\text { Stroke: } 4.6^{\star} \\
\text { Bleeding: } 1.2^{\star}\end{array}$ & $\begin{array}{l}\text { Stroke: } 2.60(2.00 \\
\text { to } 3.38) \\
\text { Bleeding: } 2.42 \\
\text { (1.44 to } 4.05) \\
\text { All cause mortality: } \\
0.82(0.74 \text { to } 0.91)\end{array}$ & $\begin{array}{l}\text { In older patients, } \\
\text { anticoagulation } \\
\text { was associated with } \\
\text { increased stroke and } \\
\text { bleeding but reduced } \\
\text { mortality }\end{array}$ \\
\hline
\end{tabular}

$\mathrm{AF}=$ atrial fibrillation; eGFR=estimated glomerular filtration rate in $\mathrm{mL} / \mathrm{min} / 1.73 \mathrm{~m}^{2}$; $\mathrm{ESRD}=$ end stage renal disease; ICD - International Classification of Diseases; $\mathrm{NA}=$ not available; $\mathrm{ND}-\mathrm{CKD}=$ nondialysis chronic kidney disease; TIA=transient ischaemic attack.

*refers to anticoagulated group rather than the whole study population

kidney disease not requiring dialysis and new onset atrial fibrillation. This finding had previously been reported only in end stage kidney disease complicated by atrial fibrillation and is at odds with a systematic review of observational studies of patients with chronic kidney disease and concomitant atrial fibrillation, which found an overall reduction in ischaemic stroke and thromboembolic events after anticoagulation. ${ }^{57}$ Several possible explanations exist.

We focused on older people who are at the highest risk of experiencing complications related to anticoagulation, resulting in the frequent discontinuation of both warfarin and direct oral anticoagulants, owing to the safety concerns of prescribers. $^{28} 58$ Our sensitivity analyses enabled us to detect events occurring up to 160 days after discontinuation of anticoagulant therapy. Some transient ischaemic attacks and ischaemic stroke events may have been subclinical and therefore not coded in the data, but we think that this is unlikely given that our event rates for all outcomes were comparable to similar studies in the literature. ${ }^{30}$

Vitamin $\mathrm{K}$ antagonists, used in over $70 \%$ of the patients on anticoagulants in our study, may accelerate the development and progression of vascular calcification through carboxylation of matrix gla protein, a potent tissue bound inhibitor of calcification in the arterial wall. ${ }^{59}$ This is especially relevant to older patients, who have the highest burden of vascular calcification. Furthermore, vascular calcification is markedly accelerated in chronic kidney disease and contributes to a higher rate of cardiovascular events and mortality. ${ }^{12} 60$ Vascular calcification in older patients on anticoagulants may plausibly have led to a greater incidence of ischaemic strokes or lacunar infarcts in watershed vascular territories, although this is not known with precision. Also of concern is the finding that patients with chronic kidney disease patients are at greater risk of developing warfarin related nephropathy, ${ }^{61}$ potentially further compromising kidney function and compounding the risk of ischaemic and haemorrhagic stroke. ${ }^{62}$ Direct oral anticoagulants have also been associated with declining renal function. ${ }^{63}$

In the absence of cause specific death data, we can only speculate on the possible explanation for reduced all cause mortality in the patients taking anticoagulants. It may be attributable to a lower rate of fatal strokes and protection against subsequent myocardial events, a finding shown with both warfarin $^{64}$ and rivaroxaban. ${ }^{65}$ Although our groups were well matched, we cannot exclude the possibility of residual confounding by receipt of anticoagulation. Our finding of increased haemorrhage in patients taking anticoagulants corroborates several existing studies. $^{19} 212430$ Haemostatic dysfunction occurs early in chronic kidney disease, with uraemic toxins augmenting bleeding risk by altering platelet function 
both in terms of recruitment and activity, and this is accentuated by anticoagulation. ${ }^{12256667}$

To the best of our knowledge, this is the largest study to consider the efficacy and safety of giving anticoagulants to older patients with atrial fibrillation and chronic kidney disease in terms of ischaemic stroke, risk of bleeding, and all cause mortality. We used an established sentinel network of 110 UK primary care practices spanning 2.73 million patients, known to be representative of the general UK population. ${ }^{323}$ The chronic kidney disease epidemiology collaboration creatinine equation was chosen as a surrogate marker of kidney function, now widely acknowledged as the most accurate marker currently available in routine clinical practice. ${ }^{68} \mathrm{~A}$ further strength was the relatively long follow-up period, almost twice as long as a comparable study in this clinical scenario. ${ }^{30}$

Our work is not without limitations. The study population was derived from real world evidence with the inherent limitations of diagnostic coding and case ascertainment. ${ }^{69}$ Misclassification bias may have occurred as we were unable to review electrocardiography and neuroimaging findings. We cannot exclude the possibility that some clinical coding was incomplete resulting in events being undetected. Reassuringly, our stroke and mortality rates are similar to a comparable study in this setting. ${ }^{30}$ Haemorrhage rates were lower in our work but we used restrictive code based definitions for gastrointestinal and cerebral bleeding, rather than non-specific indicators such as the need for a blood transfusion that are used in other studies. ${ }^{30}$ Severity of stroke is not readily available from the primary care record, so this could not be assessed.

Our study lacked the statistical power to undertake separate sub-analyses for gastrointestinal and cerebral bleeds. Despite well matched groups after propensity score matching, we cannot exclude that the reported associations were confounded by indication. Those taking anticoagulants may have had an inherent increased baseline rate of stroke. Furthermore, an assumption was that patients received adequate warfarin to put them in the therapeutic range of the international normal ratio, though this may be harder to achieve consistently in severe chronic kidney disease. ${ }^{70}$ We need robust randomised controlled trials to explore whether the reported associations in the present study are causal.

Our work is based on dispensed prescriptions for anticoagulant drugs; we did not examine data on patient adherence, so our findings should be interpreted with caution. Lastly, despite our large cohort, the proportion of patients receiving direct oral anticoagulants was small, so a comparison with vitamin $\mathrm{K}$ antagonists could not be undertaken. Future randomised controlled trials will provide clarity on this little studied management conundrum. ${ }^{71}$

\section{Conclusions}

Anticoagulation with vitamin $\mathrm{K}$ antagonists and, more recently, direct oral anticoagulants has been clearly shown to mitigate the risk of thromboembolism in patients with atrial fibrillation in the general population. Applying this approach to older people with chronic kidney disease who develop atrial fibrillation may not be appropriate, because the present study shows a higher bleeding rate, and an increase, rather than reduction, in ischaemic stroke. The lower all cause mortality in those receiving anticoagulation in our study may reflect an undefined protective effect of anticoagulation.

The main clinical implication of our findings is the considerable uncertainty about the best approach to starting and managing anticoagulation in the setting of new onset atrial fibrillation in non-dialysis chronic kidney disease. Few reports are available, and their main findings are discordant, showing reduced stroke, ${ }^{31}$ no effect on stroke, ${ }^{21} 30$ and increased stroke in this present study. The most pressing need is for real world randomised controlled trials comparing no anticoagulation (placebo) with vitamin $\mathrm{K}$ antagonist or taking a hybrid approach of placebo versus direct oral anticoagulant versus vitamin $\mathrm{K}$ antagonists. ${ }^{71}$ Meanwhile, given the present lack of guidelines, the decision to start anticoagulant treatment in patients with new onset atrial fibrillation should be made on an individual basis, weighing up the known risks and potential benefits and, where possible, taking into account patients' wishes.

The authors thank all of the patients and practices that are members of the RCGP Research and Surveillance Centre and allow their data to be shared; EMIS, In Practice Systems and TPP SystmOne who helped facilitate data extraction; Apollo Medical Systems for expertise in secure data processing; the core surveillance function of RCGP Research and Surveillance Centre, which is funded by Public Health England; Jeremy van Vlymen for his assistance using the software package R; Rachel Byford and Julian Sherlock, SQL developers, for their help with database management and data extraction.

Contributors: All authors contributed to the design, analysis, interpretation of data, drafting the article, or revising it critically for important intellectual content and approved the final version to be published. AJC is the senior and corresponding author and guarantor.

Funding: None.

Competing interests: All authors have completed the Unified Competing Interest form (available on request from the corresponding author) and declare: AJC has received institutional grants and personal fees related to advice to Boehringer Ingelheim, Bayer, Daiichi Sankyo, and Pfizer/BMS, outside the submitted work; SdL reports grants from Darzi Fellow attached to the department, grants from NIHR Research for Patient Benefit, grants from Eli Lilly Real World Evidence Centre, grants from Astra-Zeneca, outside the submitted work; SK, AM, AC, $\mathrm{MH}, \mathrm{PG}, \mathrm{S}$ ) and DG have nothing to declare.

Transparency: The senior author (AJC) affirms that the manuscript is an honest, accurate, and transparent account of the study being reported; that no important aspects of the study have been omitted; and that any discrepancies from the study as planned (and, if relevant, registered) have been explained.

This is an Open Access article distributed in accordance with the Creative Commons Attribution Non Commercial (CC BY-NC 4.0) license, which permits others to distribute, remix, adapt, build upon this work non-commercially, and license their derivative works on different terms, provided the original work is properly cited and the use is noncommercial. See: http://creativecommons.org/licenses/by-nc/4.0/.

1 Ziff OJ, Camm AJ. Individualized approaches to thromboprophylaxis in atrial fibrillation. Am Heart / 2016;173:143-58. doi:10.1016/ j.ahj.2015.10.021.

2 Camm AJ, Kirchhof P, Lip GY, et al, European Heart Rhythm AssociationEuropean Association for Cardio-Thoracic Surgery. Guidelines for the management of atrial fibrillation: the Task Force for the Management of Atrial Fibrillation of the European Society of Cardiology (ESC). Eur Heart J 2010;31:2369-429. doi:10.1093/ eurheartj/ehq278. 
3 Murray CJ, Vos T, Lozano R, et al. Disability-adjusted life years (DALYS) for 291 diseases and injuries in 21 regions, 1990-2010: a systematic analysis for the Global Burden of Disease Study 2010. Lancet 2012;380:2197-223. doi:10.1016/S01406736(12)61689-4.

4 Fuster V, Rydén LE, Cannom DS, et al, American College of Cardiology/American Heart Association Task Force on Practice GuidelinesEuropean Society of Cardiology Committee for Practice GuidelinesEuropean Heart Rhythm AssociationHeart Rhythm Society. ACC/AHA/ESC 2006 Guidelines for the Management of Patients with Atrial Fibrillation: a report of the American College of Cardiology/ American Heart Association Task Force on Practice Guidelines and the European Society of Cardiology Committee for Practice Guidelines (Writing Committee to Revise the 2001 Guidelines for the Management of Patients With Atrial Fibrillation): developed in collaboration with the European Heart Rhythm Association and the Heart Rhythm Society. Circulation 2006;114:e257-354. doi:10.1161/CIRCULATIONAHA.106.177292.

5 Chugh SS, Havmoeller R, Narayanan K, et al. Worldwide epidemiology of atrial fibrillation: a Global Burden of Disease 2010 Study. Circulation 2014;129:837-47. doi:10.1161/ CIRCULATIONAHA.113.005119.

6 Benjamin EJ, Wolf PA, D’Agostino RB, Silbershatz H, Kannel WB, Levy D. Impact of atrial fibrillation on the risk of death: the Framingham Heart Study. Circulation 1998;98:946-52. doi:10.1161/01.CIR.98.10.946

7 Go AS, Hylek EM, Phillips KA, et al. Prevalence of diagnosed atrial fibrillation in adults: national implications for rhythm management and stroke prevention: the AnTicoagulation and Risk Factors in Atria Fibrillation (ATRIA) Study. JAMA 2001;285:2370-5. doi:10.1001/ jama.285.18.2370

8 Kim MH, Johnston SS, Chu BC, Dalal MR, Schulman KL. Estimation of total incremental health care costs in patients with atrial fibrillation in the United States. Circ Cardiovasc Qual Outcomes 2011;4:313-20. doi:10.1161/CIRCOUTCOMES.110.958165.

9 Lee WC, Lamas GA, Balu S, Spalding J, Wang Q, Pashos CL. Direct treatment cost of atrial fibrillation in the older American population: a Medicare perspective. J Med Econ 2008;11:281-98. doi:10.3111/13696990802063425

10 Stewart S, Murphy NF, Walker A, McGuire A, McMurray JJ. Cost of an emerging epidemic: an economic analysis of atrial fibrillation in the UK. Heart 2004;90:286-92. doi:10.1136/hrt.2002.008748

11 Soliman EZ, Prineas RJ, Go AS, et al, Chronic Renal Insufficiency Cohort (CRIC) Study Group. Chronic kidney disease and prevalent atrial fibrillation: the Chronic Renal Insufficiency Cohort (CRIC). Am Heart / 2010;159:1102-7. doi:10.1016/j.ahj.2010.03.027.

12 Kumar S, Bogle R, Banerjee D. Why do young people with chronic kidney disease die early? World J Nephrol 2014;3:143-55. doi:10.5527/win.v3.i4.143.

13 Nimmo C, Wright M, Goldsmith D. Management of atrial fibrillation in chronic kidney disease: double trouble. Am Heart J 2013;166:230-9. doi:10.1016/j.ahj.2013.05.010.

14 Kooiman J, van Rein N, Spaans B, et al. Efficacy and safety of vitamin K-antagonists (VKA) for atrial fibrillation in non-dialysis dependent chronic kidney disease. PLoS One 2014;9:e94420. doi:10.1371/ journal.pone.0094420.

15 Roldán V, Marín F, Fernández H, et al. Renal impairment in a "real-life" cohort of anticoagulated patients with atrial fibrillation (implications for thromboembolism and bleeding). Am J Cardiol 2013;111. 1159-64. doi:10.1016/j.amjcard.2012.12.045.

16 Lai HM, Aronow WS, Kalen P, et al. Incidence of thromboembolic stroke and of major bleeding in patients with atrial fibrillation and chronic kidney disease treated with and without warfarin. Int J Nephrol Renovasc Dis 2009;2:33-7.

17 Abdelhafiz AH, Myint MP, Tayek JA, Wheeldon NM. Anemia, hypoalbuminemia, and renal impairment as predictors of bleeding complications in patients receiving anticoagulation therapy for nonvalvular atrial fibrillation: a secondary analysis. Clin Ther 2009;31:1534-9. doi:10.1016/j.clinthera.2009.07.015.

18 Bonde AN, Lip GY, Kamper AL, et al. Net clinical benefit of antithrombotic therapy in patients with atrial fibrillation and chronic kidney disease: a nationwide observational cohort study. J Am Coll Cardiol 2014;64:2471-82. doi:10.1016/j.jacc.2014.09.051

19 Baneriee A, Fauchier L, Vourc'h P, et al. A prospective study of estimated glomerular filtration rate and outcomes in patients with atrial fibrillation: the Loire Valley Atrial Fibrillation Project. Chest 2014:145:1370-82. doi:10.1378/chest.13-2103.

20 Carrero JJ, Evans M, Szummer K, et al. Warfarin, kidney dysfunction, and outcomes following acute myocardial infarction in patients with atrial fibrillation. JAMA 2014;311:919-28. doi:10.1001/ jama.2014.1334.

21 Olesen JB, Lip GY, Kamper AL, et al. Stroke and bleeding in atrial fibrillation with chronic kidney disease. N Engl J Med 2012;367: 625-35. doi:10.1056/NEJMoa1105594.
22 Bonde AN, Lip GY, Kamper AL, et al. Renal function and the risk of stroke and bleeding in patients with atrial fibrillation: an observational cohort study. Stroke 2016;47:2707-13. doi:10.1161/ STROKEAHA.116.014422.

23 Coresh J, Astor BC, Greene T, Eknoyan G, Levey AS. Prevalence of chronic kidney disease and decreased kidney function in the adult US population: Third National Health and Nutrition Examination Survey. Am J Kidney Dis 2003;41:1-12. doi:10.1053/ ajkd.2003.50007.

24 Jun M, James MT, Manns BJ, et al, Alberta Kidney Disease Network. The association between kidney function and major bleeding in older adults with atrial fibrillation starting warfarin treatment: population based observational study. BMJ 2015;350:h246. doi:10.1136/bmj.h246.

$25 \mathrm{Ng} \mathrm{KP}$, Edwards NC, Lip GY, Townend JN, Ferro CJ. Atrial fibrillation in CKD: balancing the risks and benefits of anticoagulation. Am I Kidney Dis 2013:62:615-32. doi:10.1053/j.ajkd.2013.02.381.

26 Andreotti F, Rocca B, Husted S, et al, ESC Thrombosis Working Group. Antithrombotic therapy in the older: expert position paper of the European Society of Cardiology Working Group on Thrombosis. Eur Heart J 2015;36:3238-49. doi:10.1093/eurheartj/ehv304.

27 Reinecke H, Brand E, Mesters R, et al. Dilemmas in the management of atrial fibrillation in chronic kidney disease. / Am Soc Nephrol 2009;20:705-11. doi:10.1681/ASN.2007111207.

28 Hylek EM, Evans-Molina C, Shea C, Henault LE, Regan S Major hemorrhage and tolerability of warfarin in the first year of therapy among older patients with atrial fibrillation. Circulation 2007;115:2689-96. doi:10.1161/ CIRCULATIONAHA.106.653048.

29 Biteker M, Başaran Ö, Doğan V, et al. Real-world clinical characteristics and treatment patterns of individuals aged 80 and older with nonvalvular atrial fibrillation: results from the real-life multicenter survey evaluating stroke study. J Am Geriatr Soc 2017;65:1684-90. doi:10.1111/jgs.14855.

30 Keskar V, McArthur E, Wald R, et al. The association of anticoagulation, ischemic stroke, and hemorrhage in older adults with chronic kidney disease and atrial fibrillation. Kidney Int 2017;91:928-36. doi:10.1016/j.kint.2016.10.017

31 Jun M, James MT, Ma Z, et al, Alberta Kidney Disease Network. Warfarin initiation, atrial fibrillation, and kidney function: comparative effectiveness and safety of warfarin in older adults with newly diagnosed atrial fibrillation. Am J Kidney Dis 2017;69:734-43. doi:10.1053/j.ajkd.2016.10.018

32 Correa A, Hinton W, McGovern A, et al. Royal College of General Practitioners Research and Surveillance Centre (RCGP RSC) sentinel network: a cohort profile. BMJ Open 2016;6:e011092. doi:10.1136/ bmjopen-2016-011092.

33 McGovern A, Hinton W, Correa A, Munro N, Whyte M, de Lusignan S. Real-world evidence studies into treatment adherence, thresholds for intervention and disparities in treatment in people with type 2 diabetes in the UK. BMJ Open 2016;6:e012801. doi:10.1136/ bmjopen-2016-012801.

34 von Elm E, Altman DG, Egger M, Pocock SJ, Gøtzsche PC, Vandenbroucke JP, et al, STROBE Initiative. The strengthening the reporting of observational studies in epidemiology (STROBE) statement: guidelines for reporting observational studies. Lancet 2007;370:1453-7. doi:10.1016/S0140-6736(07)61602-X

35 Levey AS, Stevens LA, Schmid CH, et al, CKD-EPI (Chronic Kidney Disease Epidemiology Collaboration). A new equation to estimate glomerular filtration rate. Ann Intern Med 2009;150:604-12. doi:10.7326/0003-4819-150-9-200905050-00006

36 Giugliano RP, Ruff CT, Braunwald E, et al, ENGAGE AF-TIMI 48 Investigators. Edoxaban versus warfarin in patients with atrial fibrillation. N Engl J Med 2013;369:2093-104. doi:10.1056/NEJMoa1310907.

37 Connolly SJ, Ezekowitz MD, Yusuf S, et al, RE-LY Steering Committee and Investigators. Dabigatran versus warfarin in patients with atrial fibrillation. N Engl J Med 2009;361:1139-51. doi:10.1056/ NEJMoa0905561.

38 Granger CB, Alexander JH, McMurray J), et al, ARISTOTLE Committees and Investigators. Apixaban versus warfarin in patients with atrial fibrillation. N Engl J Med 2011;365:981-92. doi:10.1056/ NEJMoa1107039.

39 Patel MR, Mahaffey KW, Garg J, et al, ROCKET AF Investigators. Rivaroxaban versus warfarin in nonvalvular atrial fibrillation. N Engl) Med 2011;365:883-91. doi:10.1056/NEJMoa1009638.

40 de Lusignan S. Codes, classifications, terminologies and nomenclatures: definition, development and application in practice. Inform Prim Care 2005;13:65-70.

41 Liaw ST, Rahimi A, Ray P, et al. Towards an ontology for data quality in integrated chronic disease management: a realist review of the literature. Int J Med Inform 2013;82:10-24. doi:10.1016/j. ijmedinf.2012.10.001.

42 Lévesque LE, Hanley JA, Kezouh A, Suissa S. Problem of immortal time bias in cohort studies: example using statins for preventing progression of diabetes. BM/ 2010;340:b5087. doi:10.1136/ bmj.b5087. 
43 Gallagher AM, van Staa TP, Murray-Thomas T, et al. Populationbased cohort study of warfarin-treated patients with atrial fibrillation: incidence of cardiovascular and bleeding outcomes. BM Open 2014;4:e003839. doi:10.1136/bmjopen-2013-003839.

44 Moran GM, Calvert M, Feltham MG, Ryan R, Marshall T. A retrospective cohort study to investigate fatigue, psychological or cognitive impairment after TIA: protocol paper. BMJ Open 2015;5:e008149. doi:10.1136/bmjopen-2015-008149.

45 Allan V, Banerjee A, Shah AD, et al. Net clinical benefit of warfarin in individuals with atrial fibrillation across stroke risk and across primary and secondary care. Heart 2017;103:210-8. doi:10.1136/ heartjnl-2016-309910.

46 Go AS, Mozaffarian D, Roger VL, et al, American Heart Association Statistics Committee and Stroke Statistics Subcommittee. Heart disease and stroke statistics--2013 update: a report from the American Heart Association. Circulation 2013;127:e6-245. doi:10.1161/CIR.0b013e31828124ad.

47 Abel GA, Barclay ME, Payne RA. Adjusted indices of multiple deprivation to enable comparisons within and between constituent countries of the UK including an illustration using mortality rates. BMJ Open 2016;6:e012750. doi:10.1136/bmjopen-2016-012750.

48 Grambsch PM, Therneau TM. Proportional hazards tests and diagnostics based on weighted residuals. Biometrika 1994;81: 515-26doi:10.1093/biomet/81.3.515.

49 Kirchhof P, Benussi S, Kotecha D, et al. 2016 ESC Guidelines for the management of atrial fibrillation developed in collaboration with EACTS. Eur Heart / 2016;37:2893-962. doi:10.1093/eurheartj/ ehw210.

50 Kernan WN, Ovbiagele B, Black HR, et al, American Heart Association Stroke Council, Council on Cardiovascular and Stroke Nursing, Council on Clinical Cardiology, and Council on Peripheral Vascular Disease. Guidelines for the prevention of stroke in patients with stroke and transient ischemic attack: a guideline for healthcare professionals from the American Heart Association/American Stroke Association. Stroke 2014;45:2160-236. doi:10.1161/ STR.0000000000000024.

51 Bansal VK, Herzog CA, Sarnak MJ, et al. Oral anticoagulants to prevent stroke in nonvalvular atrial fibrillation in patients with CKD stage 5D: an NKF-KDOQI controversies report. Am J Kidney Dis 2017;70: 859-68. doi:10.1053/j.ajkd.2017.08.003

52 Chan KE, Lazarus JM, Thadhani R, Hakim RM. Warfarin use associates with increased risk for stroke in hemodialysis patients with atrial fibrillation. J Am Soc Nephrol 2009;20:2223-33. doi:10.1681/ ASN.2009030319.

53 Wizemann V, Tong L, Satayathum S, et al. Atrial fibrillation in hemodialysis patients: clinical features and associations with anticoagulant therapy. Kidney Int 2010;77:1098-106. doi:10.1038/ ki.2009.477

54 Phelan PJ, O'Kelly P, Holian J, et al. Warfarin use in hemodialysis patients: what is the risk? Clin Nephrol 2011;75:204-11. doi:10.5414/CN106481

55 Wang TK, Sathananthan J, Marshall M, Kerr A, Hood C. Relationships between anticoagulation, risk scores and adverse outcomes in dialysis patients with atrial fibrillation. Heart Lung Circ 2016;25 243-9. doi:10.1016/j.hlc.2015.08.012

56 Tan J, Liu S, Segal JB, Alexander GC, McAdams-DeMarco M. Warfarin use and stroke, bleeding and mortality risk in patients with end stage renal disease and atrial fibrillation: a systematic review and metaanalysis. BMC Nephrol 2016;17:157. doi:10.1186/s12882-0160368-6.
57 Dahal K, Kunwar S, Rijal J, Schulman P, Lee J. Stroke, major bleeding, and mortality outcomes in warfarin users with atrial fibrillation and chronic kidney disease: a meta-analysis of observational studies. Chest 2016;149:951-9. doi:10.1378/chest.15-1719.

58 Halperin JL, Hankey GJ, Wojdyla DM, et al, ROCKET AF Steering Committee and Investigators. Efficacy and safety of rivaroxaban compared with warfarin among older patients with nonvalvular atrial fibrillation in the Rivaroxaban Once Daily, Oral, Direct Factor Xa Inhibition Compared With Vitamin K Antagonism for Prevention of Stroke and Embolism Trial in Atrial Fibrillation (ROCKET AF). Circulation 2014;130:138-46. doi:10.1161/ CIRCULATIONAHA.113.005008.

59 Holden RM, Booth SL. Vascular calcification in chronic kidney disease: the role of vitamin K. Nat Clin Pract Nephrol 2007;3:522-3. doi:10.1038/ncpneph0601.

60 Böhm M, Ezekowitz MD, Connolly SI, et al. Changes in renal function in patients with atrial fibrillation: an analysis from the RE-LY trial. J Am Coll Cardiol 2015;65:2481-93. doi:10.1016/j.jacc.2015.03.577.

61 Brodsky SV, Nadasdy T, Rovin BH, et al. Warfarin-related nephropathy occurs in patients with and without chronic kidney disease and is associated with an increased mortality rate. Kidney Int 2011;80: 181-9. doi:10.1038/ki.2011.44.

62 Lee M, Saver JL, Chang KH, Liao HW, Chang SC, Ovbiagele B. Low glomerular filtration rate and risk of stroke: meta-analysis. BMJ 2010;341:c4249. doi:10.1136/bmj.c4249.

63 Yao X, Tangri N, Gersh BJ, et al. Renal outcomes in anticoagulated patients with atrial fibrillation. J Am Coll Cardiol 2017;70:2621-32 doi:10.1016/j.jacc.2017.09.1087

64 Lip GY, Lane DA. Does warfarin for stroke thromboprophylaxis protec against MI in atrial fibrillation patients? Am J Med 2010;123:785-9. doi:10.1016/j.amjmed.2010.01.031.

65 Eikelboom JW, Connolly SJ, Bosch J, et al, COMPASS Investigators. Rivaroxaban with or without Aspirin in Stable Cardiovascular Disease. N Engl I Med 2017;377:1319-30. doi:10.1056/NEJMoa1709118.

66 Thijs A, Nanayakkara PW, Ter Wee PM, Huijgens PC, van Guldener C, Stehouwer CD. Mild-to-moderate renal impairment is associated with platelet activation: a cross-sectional study. Clin Nephrol 2008;70:325-31.

67 Burlacu A, Genovesi S, Ortiz A, et al. The quest for equilibrium: exploring the thin red line between bleeding and ischaemic risks in the management of acute coronary syndromes in chronic kidney disease patients. Nephrol Dial Transplant 2017;32:1967-76. doi:10.1093/ndt/gfx041.

68 Michels WM, Grootendorst DC, Verduijn M, Elliott EG, Dekker FW, Krediet RT. Performance of the Cockcroft-Gault, MDRD, and new CKD-EPI formulas in relation to GFR, age, and body size. Clin J Am So Nephrol 2010;5:1003-9. doi:10.2215/CJN.06870909.

69 de Lusignan S, Sadek K, McDonald H, et al. Call for consistent coding in diabetes mellitus using the Royal College of General Practitioners and NHS pragmatic classification of diabetes. Inform Prim Care 2012;20:103-13.

70 Szummer K, Gasparini A, Eliasson S, et al. Time in therapeutic range and outcomes after warfarin initiation in newly diagnosed atrial fibrillation patients with renal dysfunction. J Am Heart Assoc 2017;6:e004925. doi:10.1161/JAHA.116.004925.

71 Kimachi M, Furukawa TA, Kimachi K, Goto Y, Fukuma S, Fukuhara S. Direct oral anticoagulants versus warfarin for preventing stroke and systemic embolic events among atrial fibrillation patients with chronic kidney disease. Cochrane Database Syst Rev 2017;11:CD011373. doi:10.1002/14651858.CD011373.pub2. 